\title{
PROBLEMS OF TRADE FINANCING DEVELOPMENT IN THE RUSSIAN FEDERATION
}

\author{
Nikolova Lyudmila \\ Peter The Great Saint-Petersburg Polytechnic University, Saint-Petersburg, Russia
}

From the standpoint of enterprises, searching for the minimum-risk methods and ways of organizing settlements in foreign trade is always a topical problem. The research study identifies the problems of trade finance in the Russian Federation (RF) after the sanctions have been imposed. The key features of trade finance management are formulated. The influence of economic sanctions on trade financing mechanisms is analyzed. Some mechanisms are considered for using a documentary letter of credit, one of the most popular trade financial instruments in international settlements today. Measures for eliminating the factors restraining the growing use of trade finance instruments and the possibility of their implementation under the conditions of current economic sanctions are grounded. System analysis methods and techniques, analogy methods, expert assessments and projection methods are used as part of this research study.

Keywords: trade financing; documentary letter of credit; economic sanctions, projection methods; Russian Federation.

\section{Introduction}

The volume of foreign trade operations of the Russian Federation (RF) continues to decline due to the economic sanctions imposed in 2014 (and prolonged relatively recently).

The sanctions have already affected and continue to affect negatively trade financing of the Russian Federation. Some of the foreign banks have reduced expositions on Russian banks and country expositions to the Russian Federation as a whole, the level of trust between Russian and Western counteragents have also lowered significantly. The overall economic conditions in the country have worsened: GDP growth rate is declining; the volumes of both exports and imports went down to at least the level of 2008.

Identification of problems and justification of measures to eliminate the factors that inhibit the growth in the use of trade finance instruments in the Russian Federation is an urgent task, considering the current economic situation.

According to leading experts in the field, the use of letters of credit, documentary collections, guarantees etc. in international settlements and trade financing, among all the

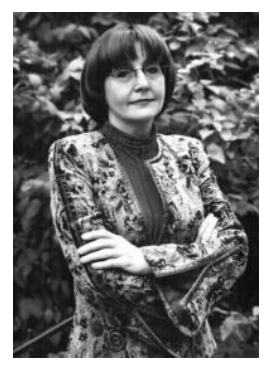

\section{Lyudmila Nikolova}

Doctor of Economic Sciences, Assistant Professor, the Institute of Industrial Management, Economics and Trade, Peter The Great Saint-Petersburg Polytechnic University, SaintPetersburg, Russia

Research interests: innovation and investment management, financial management, financing and management of international investment programs, economics of organizations and management of enterprises and industries, accounting, economic analysis, business performance evaluation

E-mail: nikolova_lv@spbstu.ru 
variety of settlement instruments, is becoming more and more topical for Russian enterprises, thus, the volumes of such documents in use are growing.

In this study we have analyzed the status of trade and export operations and made substantiated proposals for increasing their volume in the RF under current economic sanctions.

As it is commonly known, the volume of trade and export operations always influences the GDP indicator. To increase the volume of trade and export operations and accordingly GDP it is necessary:

- to increase the volume of international trade with Asian countries;

- to accelerate the process of providing state financial as well as non-financial support for exporters;

- to pay special attention to the Export Credit Insurance Agency of Russia (ECIAR) in part of financing export transactions.

The data of the Federal State Statistics Service (Rosstat) and its territorial body for St. Petersburg and the Leningrad Region (Petrostat) serve as the initial data basis for our study.

\section{The impact of economic sanctions on trade financing}

Some of the problems with trade finance actually preceded the period when the current economic sanctions were introduced. Along with the legislation, the mechanisms of trade financing are impacted by the condition of the banking sector. Let us review briefly the state of the banking system before 2014 and today.

The state of the banking system in the Russian Federation before 2014:

As of early 2014, Russian banking system was almost completely restored after the global financial crisis of 2008-2009. Slight growth of the economy, positive balance of payments, growing retail sector and other positive macroeconomic indicators allowed Russian banks raise quite sufficient funds at both capital markets and specialized trade finance markets. Western banks were ready to supply loans to the largest Russian banks for the purpose of trade financing for the period of 5 to 7 years.

Before the sanctions medium-sized banks used to have, among other things, trade finance programs of interstate financial institutions, such as the International Bank for Reconstruction and Development (IBRD), the European Bank for Reconstruction and Development (EBRD), and the International Finance Corporation (IFC). Special syndicates were involved in financing foreign trade - both with participation of the abovementioned structures and without them.

The condition of the country's banking system and economy after the Western sanctions were imposed back in 2014:

According to Rosstat, Russia's GDP decreased by $3.7 \%$ in 2015, while without foreign trade, the decline would have been $9.9 \%$. A very similar situation was in 2009, straight after the global crisis, when Russia's GDP decreased by almost $8 \%$. However, excluding foreign trade, the decline was as noticeable as $13 \%$.

In 2015, the net export was the only component to make a positive contribution to the GDP growth rate. In 2016, the GDP declined by another $0.6 \%$ in comparison to 2015.

The nature of the current crisis in Russia differs significantly from the previous two economic downturns - the crisis of 1998 and that of 2008, as well as the reasons why they occurred. 


\section{PROBLEMS OF TRADE FINANCING DEVELOPMENT}

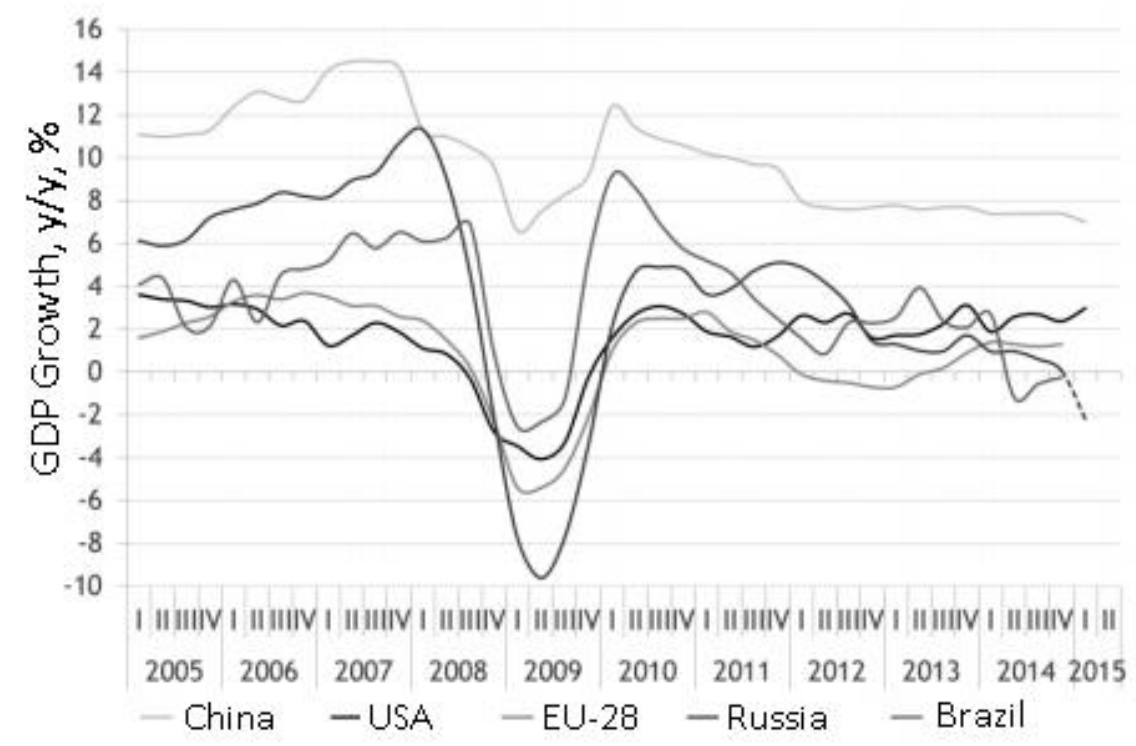

Figure 1 - Quarterly GDP dynamics of the world leading countries, 2005-2015 (Source: https://www.wto.org/english/res_e/statis_e/wts2015_e/wts2015_e.pdf )

Table 1 - The contribution of the demand components to Russia's GDP growth, 2007 to 2015

(Source: Rosstat)

\begin{tabular}{|c|c|c|c|c|c|c|c|c|c|}
\hline & 2007 & 2008 & 2009 & 2010 & 2011 & 2012 & 2013 & 2014 & 2015 \\
\hline $\begin{array}{c}\text { GDP share } \\
\text { growth, in \% }\end{array}$ & 8,5 & 5,2 & $-7,8$ & 4,5 & 4,3 & 3,5 & 1,3 & 0,7 & $-3,7$ \\
\hline
\end{tabular}

The 1998 crisis took place against a rather difficult economic situation in the country overall and was triggered by a fall in commodity prices and the financial crisis in the SouthEast Asia.

The crisis of 2008 in Russia began as part of the global crisis and affected almost all sectors of the national economy. Foreign trade felt the impact of this world crisis in late 2008 already and this impact was more dramatic, since the dynamics of foreign trade turnover declining during the 2008-2009 crisis was very much similar to the trend of the 1998 crisis, At the same time, the depth of the fall during 2014-2015 was quite comparable with the 2008 crisis (see Fig. 2). 


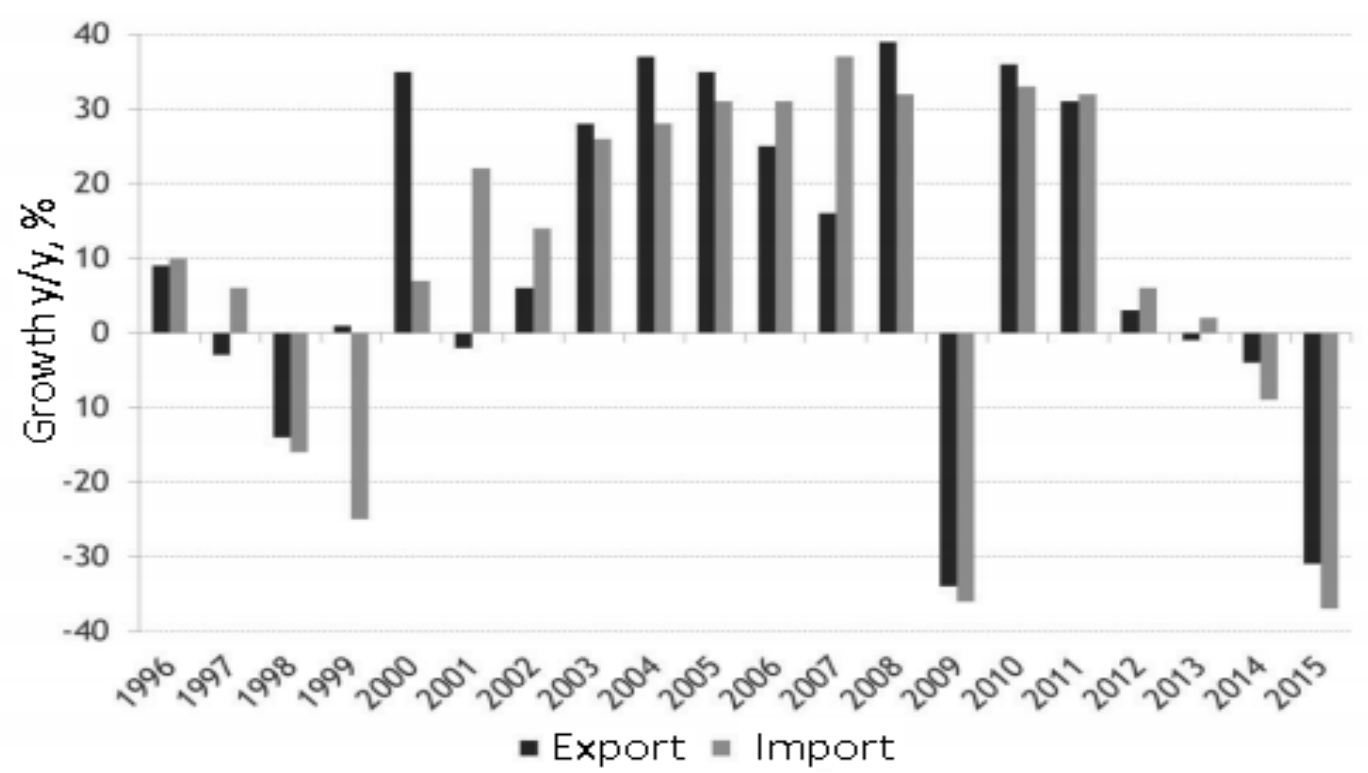

Figure 2 - Dynamics of Russian exports and imports of goods, in \%, 1996 to 2015 (Source: https://www.wto.org/english/res_e/statis_e/wts2015_e/wts2015_e.pdf )

The current crisis, which is taking place against the backdrop of a drastic and prolonged decline in the world energy prices and is also involving an entirely new factor sanctions, has affected not only the volumes of foreign trade, but also its structure.

\section{Analysis of the seasonally adjusted series}

Our analysis of the seasonally adjusted series shows that the volume of exports has stagnated since the middle of 2011 (Fig. 3) and then began to decline sharply since the mid 2014, equaling only to $66 \%$ as of February 2016. Russia continued to strengthen its economic and geopolitical cooperation with Asian countries against the background of declining exports. Fuel and energy resources, in particular oil \& gas, remained to be the most important export commodities. According to the 2015 data, their share in the volume of exports was $63 \%$. The fall in oil prices had a negative impact on the dollar export earnings, but due to the ruble depreciation, these losses were at the 2010 average level in value terms.

Exports to the EU and the CIS countries was falling at an accelerating rate due to destabilization of their relations with Russia. The sharpest drop in supplies to the CIS countries was observed in the summer of 2014, and by February 2016 the exports to the CIS was equal to roughly $60 \%$ of its average volume back in 2010 (Fig. 3). At the same time, the share of trade with the Asia-Pacific Economic Cooperation (APEC) countries has been growing, from $21.5 \%$ in 2014 to $23 \%$ in 2015 against the background of a general decrease in the volume of export flows during the crisis period. This has been taking place primarily due to the fact that the Asia-Pacific region is gradually becoming a top-priority area for Russia's cooperation with other countries of the world.

On August 6, 2014, Russia imposed a ban on the import of certain types of products from the United States, Canada, the European Union, Norway and Australia in response to Western countries' sanctions. These measures led to a general decrease in the volume of imports, a partial change in the commodity and geographical composition of trade, changes in import prices and, as a consequence, inflation overall. However, at the same time a certain 


\section{PROBLEMS OF TRADE FINANCING DEVELOPMENT}

decrease in imports was observed in all the regions of the world. The total volume of imports in Russia reached the minimum in December 2015, amounting to $70 \%$ of the level of 2010, later the decline in imports stopped.

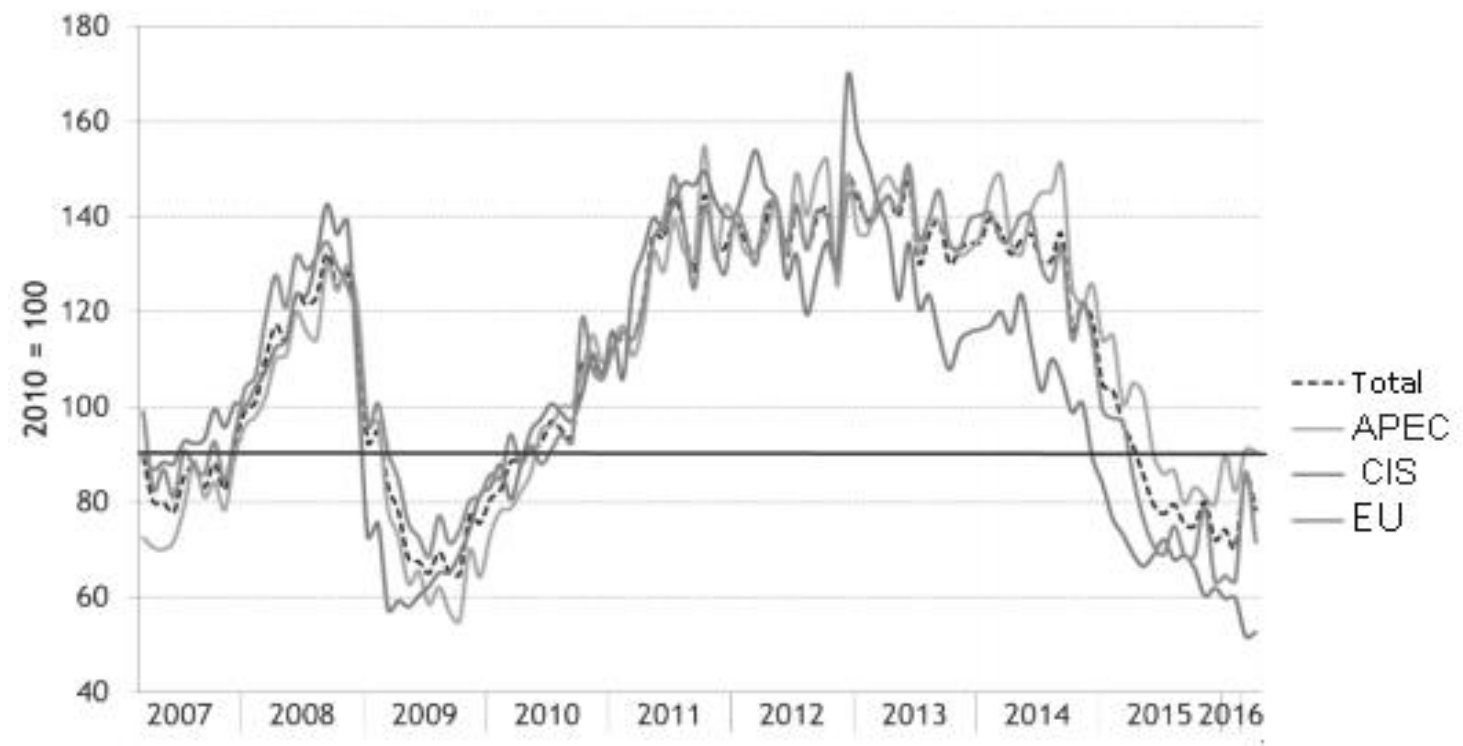

Figure 3 - Dynamics of Russia's exports by key groups of countries, 2007 to 2016, seasonally adjusted series, the average monthly value of $2010=100$.

(Source: https://www.wto.org/english/res_e/statis_e/wts2016_e/wts2016_e.pdf )

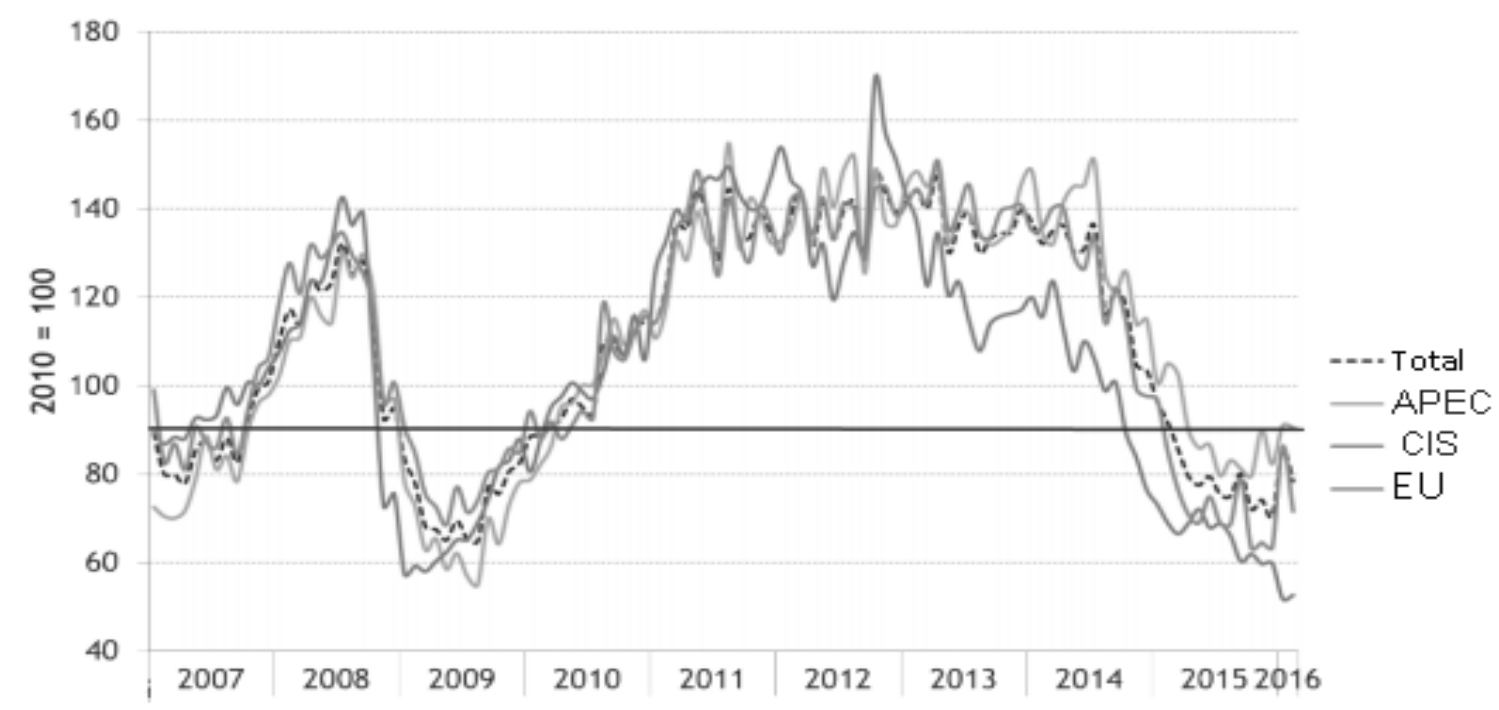

Figure 4. Dynamics of Russia's imports by key groups of countries, 2007-2016, seasonally adjusted series, the average monthly value of $2010=100$

(Source: https://www.wto.org/english/res_e/statis_e/wts2016_e/wts2016_e.pdf )

Positive trends in the import dynamics from the EU and APEC countries have been observed since the middle of 2015. But the volume of imports from the CIS continues to decline - by February 2016 it reached 52\% of the average volume as of 2010, which is 
caused, to a larger extent, by the general destabilization of Russian trade with Ukraine (Fig. 4).

The sanctions have their huge impact on trade financing in the Russian Federation, its volume is falling. Some of the foreign banks have also reduced the expositions on Russian banks and country expositions on the Russian Federation as a whole. The level of trust between Russian and Western counterparties has also lowered and the overall economic situation in the country worsened. The main reason for this is the constantly lowering volume of trade financing.

Once the sanctions were imposed, most of the interstate institutions were forced to freeze their programs and operations. A number of export credit agencies (ECAs) have become more conservative when dealing with Russia. ECA's participation allowed mediumsized banks attract rather "long" and relatively cheap credit resources to finance the supply of high-tech equipment and durable means of production to Russia. We cannot say that the ECA activities have fully stopped (formally, trade financing does not fall under any article of sanctions), but we can definitely state that the volume of transactions decreased significantly. Fig. 5 shows the dynamics in export-import transactions, which clearly demonstrates a significant decline in Russia's foreign trade operations during 2014-2015.

\section{Reasons for decline in export-import operations}

Firstly, a rather prudent approach was demonstrated by the ECAs themselves, as they began to follow the principle of "it is better to do nothing than accidentally do harm".

Secondly, at present, it is very difficult for Western financial institutions to determine whether certain goods are dual purpose equipment or not. Therefore, the principle "not to do harm" starts to be used again. For example, one of European banks was examining the transaction for the supply of personal computers to Russia for more than a month, as it suspected dual purpose equipment (computers were supplied by a US company).

Today, when Russian banks cooperate with Western banks, in addition to the KYC (Know Your Customer) procedures, banks are faced with the KYT (Know Your Transaction) concept, which also increases the time for consideration of transactions.

Thirdly, Russian customers, in particular those who buy equipment, are increasingly worried that Western producers will not fulfill their contractual obligations because of the sanctions (the so-called "performance bond risk"). The manufacturer can begin production, some of the money will be paid out of the interbank loan funds and all this can be stopped overnight with a Russian bank having already taken the client risks (Orellana, 2010).

As a result, we can conclude that once the sanctions have been imposed, the volume of trade financing has decreased significantly. Despite the fact that trade financing is not subject to the sanctions, Western banks choose to be very careful about transactions, taking into account all potential consequences. 


\section{PROBLEMS OF TRADE FINANCING DEVELOPMENT}

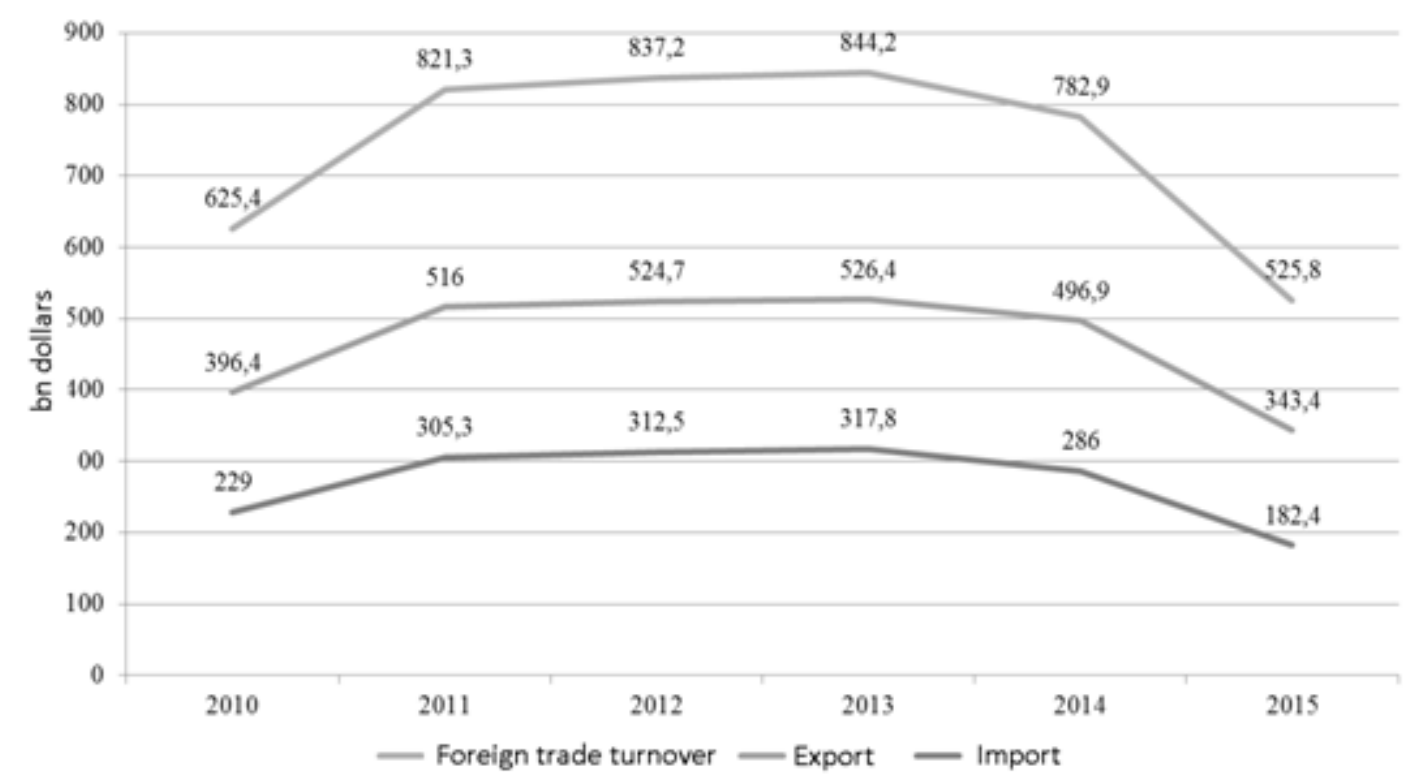

Figure 5 - Dynamics of foreign trade of the Russian Federation during 2010-2015

(Source: Statistika TsB RF, 2017)

A number of foreign banks have closed their credit lines for Russian banks (primarily, the United States' and Canadian banks). International financial institutions have closed or suspended their credit lines, in particular, IFC did, same did the IBRD (International Bank for Reconstruction and Development) and also the EBRD does not have new transactions with Russia at the moment.

The toughening compliance/control procedure have lead to the problems with customer payments since many of such payments were "getting stuck" in the chain of correspondent banks for an indefinite period of time.

Sectoral sanctions and sanctions against specific individuals and companies have lead to the inability to attract international financing for specific transactions.

\section{Proposals and conditions necessary for their implementation in trade financing in the context of economic sanctions}

Proposals for trade financing development in the Russian Federation under the current conditions of economic sanctions:

- $\quad$ to re-orient and increase the volume of international trade with Asian countries;

- to speed up the process of allocating state financial and non-financial support for exporters;

- to pay more attention to the Export Insurance Agency of Russia (EXIAR) in part of export financing transactions.

Despite today's economic and geopolitical troubles, Russia is still interested in its active participation in the global economy. We should note that in 2014 the Ministry for Economic Development of Russia prepared the draft of the National Export Strategy of 
Russia until 2030 (the work on this document began long before the introduction of antiRussian sanctions, actually). This program document outlines the measures to be taken for Russia to achieve leading positions in the global exports and thus enter the top-five exporters by 2030 along with China, the United States, Germany and Japan (Volkova, 2016). Despite the current budget deficit, funds have been allocated for the next 3 years to subsidize the interest rate in the field of export credit in the amount of 10 billion rubles per year, as well as additional funds for the capitalization of the Center for Credit and Insurance Support for Exports (CCISE) in the amount of 30 billion for the year 2017 alone (EXIAR - Export Insurance Agency of Russia, 2017).

Today, external economic relations are also supported by the state using the institutions which are relatively new for Russia. Insurance of export credits and investments, provided by the Export Insurance Agency of Russia (EXIAR), is introduced into business practice. JSC "EXIAR" has developed the Business Strategy for 2017-2020, which will ensure the adaptability of export insurance planning without significant deviations from the vitally important international indicators. In order to achieve the objectives set and increase the level of insurance support, as well as provide maximum access to insurance support for exporters and financial organizations, the Strategy defines two basic quantitative indicators STs (strategic targets) for all insurance activities of the Agency:

1) The volume of supported (insured) non-raw material exports. It determines the priority of the Agency's key objective to ensure the level of insurance support for national exports;

2) The number of supported unique exporters (excluding those coming from the SME sector). It reflects the Agency's objective to increase the level at which insurance instruments are used along with the widest possible coverage of the customer base.

The indicative values of these quantitative STs for 2017 and 2020 are determined given the results of the Agency's operations back in 2013-2014. To ensure long-term quality and sustainability of insurance operations, two ST operational indicators are defined as follows:

1) The share of cases when the periods within which the terms of insurance are defined deviate from the standard. It sets the systemic priority in the process of insurance coverage provision. The standard, whose deviation is used to calculate this target, must be defined by the Agency's governing bodies;

2) Customer satisfaction is an indicator widely used in the practice of foreign ECAs. It determines the priority of improving the quality of work with clients and Agency services. The ST values for 2017 and 2020 have been determined based on the findings of the first survey of EXIAR clients back in 2015.

\section{Conditions for implementing the Agency's strategy}

Given the established targets for the volume of Agency insurance support in 2015-2017 and up to 2020, the limit of the bank guarantees granted by the Vnesheconombank for the obligations of the EXIAR in the amount of USD 10 billion for the period of 20 years (with the state guarantees of the Russian Federation) can be reached already at the end of this year already. Given the need to confirm the credibility of the Agency at the sovereign level, 


\section{PROBLEMS OF TRADE FINANCING DEVELOPMENT}

among other things, for the recognition of the EXIAR insurance coverage by foreign borrowers, financing organizations and foreign ECAs and in order to continue operations and reach specified targets for the volume of the Agency's insurance support, the Agency will require additional security in the form of state guarantees of the Russian Federation.

In accordance with the National Export Strategy, the main importers of Russian goods will be CIS countries (also known as post-Soviet countries; a significant share here will fall on two members of the Customs Union - Belarus and Kazakhstan), and also countries of the Middle East and Latin America. The share of non-raw materials' exports to these countries is expected to increase from $45 \%$ in 2014 to $51 \%$ by 2020 , with an average annual growth in exports being about $8.4 \%$. The fastest growing areas for Russian non-raw materials exports will be the Asia-Pacific region, Latin America, here it is expected to reach the average annual growth rates of $10.1 \%$ and $13.5 \%$ respectively.

Thus, despite the currently difficult economic situation, Russia's ambition to participate more actively in the global competition, open markets and global competitiveness is very much explicit. To achieve this goal, such tools should be used as provision and insurance of export credits, subsidized interest rates, insurance of business and political risks, provision of state loans and guarantees, establishment of a trade financing association, partial refusal from international settlements in dollars and transition to payments in the national currency, development of the national payment system, establishment of an efficient program of compliance monitoring and control under the conditions of global economic sanctions.

\section{Discussion and Conclusion}

1. The volume of foreign trade operations in the Russian Federation grows year by year. This type of activity is more risky than trading within the country, for a range of both political and economic reasons. Thus, in the first place, all efforts of both buyers and sellers (that is, importers and exporters) should be aimed at minimization, ideally - at complete elimination, of the related risks in order to complete successfully foreign trade transactions, preventing potential losses at the same time.

The search for the methods and mechanisms of arranging foreign settlements under minimum risks is a topical problem. The most popular of these methods/mechanisms are documentary letters of credit, bank guarantees and documentary collection.

2. In Russia, there are factors that hinder the volume of transactions with documentary letters of credit from being used more frequently. More specifically, we can observe a certain inconsistency of Russian legislation with the international rules for operations with documentary letters of credit.

3. Measures to be taken by Russian business community and state administration so that to eliminate these factors that hinder the growth in the use of documentary letters of credit should concern, in the first place, elimination of this inconsistency between Russian legislation and international rules and norms of using documentary letters of credit. Another important direction concerns the development of a mechanism for prompt adjustment of Russian legislation to changes in international practice of settlements under letters of credit.

4. The volume of trade financing transactions declined under the influence of the sanctions, the main reasons being:

- the more prudent approach of the ECAs, which follows the principle of "It is better to do nothing than accidentally do harm"; 
- Russian customers, in particular equipment buyers, are increasingly worried that Western producers will not fulfill their contractual obligations under the conditions of sanctions;

5. The major consequences from the sanctions imposed on Russian banks are as follows:

- a number of foreign banks have closed the credit lines for Russian banks (primarily those from the United States and Canada);

- international financial institutions have closed or suspended their credit lines, in particular, IFC, IBRD and EBRD;

- the toughened compliance (control) procedure leads to a range of problems with customer payments, mostly because many of these payments are "getting stuck" in Westernbased correspondent banks for an indefinite period of time.

6. Despite all the current difficulties, trade financing is the last thing that can be completely banned. It is necessary to continue working with banks, to persuade manufacturers and suppliers to take direct risks on Russian banks. In most cases neither foreign banks, nor foreign exporters are interested in maintaining strained relations (because the latter mean only economic losses for both sides involved). It is necessary to create some sort of a club or an association of trade financing which would unite the representatives of all (or nearly all) Russian banks.

One of the most important methods for minimizing the negative effects from the economic sanctions on the economy and, particularly on trade financing in the Russian Federation, is partial abandonment of the US dollar in operations and transition to settlements in national currencies. The second method is to develop the national payment system as an alternative.

7. Under the conditions of economic sanctions Russia has to reconsider its choice of partners when it comes to foreign economic activity. These days economic cooperation is always being discussed in combination with foreign policy issues, security issues etc. All these issues are often actively discussed at the summits of the BRICS and SCO (Shanghai Cooperation Organization). Among the BRICS members, as of today, India seems to be quite a promising partner for Russia in foreign trade and economic cooperation overall.

8. Currently, state support of foreign economic relations is carried out via the institutions that are somewhat new for Russia. In particular, insurance of export credits and investments provided by the Export Insurance Agency of Russia (EXIAR) is introduced into business practice.

9. Reasonability of the proposed changes is caused by the need to increase Russian non-raw material exports, which becomes an especially acute issue in the context of economic sanctions. Thus, despite all the difficulties of the current economic situation, Russia's choice to still participate in the global competition and be present at open markets globalwide is irreversible.

In order to support Russian manufacturers in their ambition and competitiveness growth, it is necessary to develop both financial and non-financial mechanisms so that to stimulate exports, primarily those of non-raw material nature. For this purpose it is necessary to use such tools as provision and insurance of export credits, subsidization of interest rates, insurance of business and political risks and provision of state loans and state guarantees.

10. Finally, it is necessary to further improve the system of state and legislative support for all types of Russian exports. The Government of the Russian Federation is undertaking 


\section{PROBLEMS OF TRADE FINANCING DEVELOPMENT}

significant efforts, which already have led to the expansion of foreign economic relations with a range of promising economic partners, in Asia in particular.

\section{References:}

Bashkova, T.V. (2015). State support of export of Russia in modern conditions. Young scientist, 1: 181-186.

Beard A. (2010). Trade Finance Handbook. USA: RR Donnelley, Crawfordsville. 224.

Beck T. (2010). Creating an Efficient Financial System: Challenges in a Global Economy. USA: World Bank Policy Research Working Paper 3856. 43.

Bhogal T. (2011). Trade finance (Finance and Capital Markets). London: Palgrave Macmillan. 180.

Bronnikova E. A. (2011). Trade Finance products and the conceptual apparatus. Factoring and Trade Finance, 4: 36-37.

Dunn M. (2010). How to Help You Get Paid, Credit \& Collections Forms \& Letters. USA: Never Dunn Publishing LLC. 123.

Egorova N. E. (2011). Enterprises and banks: interaction, economic analysis: Textbook. Moscow, 456.

Eiteman D. (2011). Multinational business finance. USA: Addison-Wesley. 648.

EXIAR - the Strategy of development of EKSAR for the period of 2015-2017. Retrieved on 20.12.2016 from: www.exiar.ru/upload/docs/Strategy\%20развития\%20ЭКСАР\%2020152017.pdf .

Fedorova N. (2011). The letter of credit is beneficial to all. In Russia it's time to create a new system of payment by documentary credit. National banking journal, 3. 20-21.

The foreign trade information portal. Retrieved on 07.11.2016 from www.ved.gov.ru/rus_export/svodniy_reestr_institutov_i_instrumentov_podderzhk.

Makarov S. H. (2010). The Role of agent Bank in the Russian system of state support of exports. International banking operations, 2: 35.

Nikolova, L., Kuporov, J. \& Rodionov, D. (2015). Economics and Society in the Era of Technological Changes and Globalization. International Journal of Economics and Financial Issues, 5. 73-79.

Nikolova, L., Rodionov, D. \& Omelianenko, A. (2014). Risk management of banks assets securitization. Life Sciences Journal, 11(11): 576-581.

Orellana, M. (2010). Export Credit Agencies and the World Trade Organization. USA: Center for International Environmental Law, 25.

Pavlovich, J. (2010). Independent documentary obligation. Walters Kluwer. 70.

Putilin, V. (2010). Operational risks at carrying out of documentary operations. International banking operations, 3. 3-4.

Venedikian, H. (2010). Global trade financing. Canada: John Wiley and Sons. 496.

Volkova, N. (2016). Analysis of international investment attractiveness of Russia and China. Collection of scientific papers of the 17th international scientific-practical conference of SPbSPU. 63-67.

Zelenov, A. (2010). Letters of Credit for Cheaper Credits. Bank Review. 1: 70-72.

Paper submitted

Paper accepted for publishing

Paper published online
21 September 2018

03 November 2018

30 November 2018 